\title{
TRABALHO DOMÉSTICO E SOCIALIZAÇÃO: estudo exploratório sobre o tema em Brasília (DF)
}

Josenilson Guilherme de Araújo

Curso: Mestrado em Sociologia

Data da Defesa: 28 de fevereiro de 2005

Orientadora: Prof $^{a}$ Dr $^{\mathrm{a}}$ Christiane Girard Ferreira Nunes

\section{Resumo}

A idéia central do presente estudo é verificar e demonstrar as relações existentes entre trabalho doméstico e socialização, refletindo sobre a vigência de valores diversos em práticas sociais concretas, negociadas e efetivadas no cotidiano de distintos grupos domésticos. Assim, procurou-se demonstrar como o trabalho doméstico porta uma carga histórico-cultural como sendo uma atribuição da mulher, de caráter gratuito, não produtivo e sem visibilidade social. A partir de considerações sócio-históricas, examinar como o trabalho doméstico é compreendido e se constrói sem referência entre o masculino e feminino, portanto, sem relação entre os gêneros. Apesar do seu caráter assistemático, considerando a objetividade das relações técnicas e sociais, os mecanismos de regulação produtiva e organizacional, de valorização e normatividade do trabalho formal, o trabalho doméstico constitui-se em fator de socialização dos indivíduos e em aspecto instaurador de identidades.

Desse modo, buscamos evidenciar, por meio dos estudos de alguns autores selecionados e de entrevistas realizadas com diferentes grupos domésticos (famílias) em algumas regiões do Distrito Federal, a importância do tema para a teoria e a investigação sociológica, já que o trabalho doméstico é considerado uma categoria de análise com implicações e dificuldades teóricas e metodológicas próprias. 
A análise também aborda o processo histórico pelo qual o trabalho doméstico é menos valorizado socialmente em relação a outras vertentes do trabalho humano.

Palavras-chave: trabalho doméstico, socialização, representações sociais. 